\title{
Opioid Use and Driving Performance
}

\author{
Keaton T. Cameron-Burr ${ }^{1}$ - Albert Conicella ${ }^{1}$ (D) Mark J. Neavyn ${ }^{1}$
}

Received: 6 November 2019 /Revised: 21 September 2020 / Accepted: 9 November 2020 / Published online: 5 January 2021

(C) American College of Medical Toxicology 2021

\begin{abstract}
Introduction The USA is in an opioid epidemic, with an increased number of individuals taking psychoactive drugs while executing the tasks of everyday life, including operating a motor vehicle. The pharmacology of opioids has been widely studied, but the effects of opioids on psychomotor function, driving performance, and the risk of motor vehicle collision remain less clear. Clinicians are faced with the challenge of controlling patient pain while also reconciling conflicting messages from the literature about how safe it is for their patients taking opioids to engage in potentially dangerous routine tasks.

Discussion This review assesses the current literature regarding opioids as they relate to neurocognitive function, driving performance, and accident risk. Manuscripts are categorized by study context and subject matter: controlled experimental administration, illicit use, prescription use, retrospective forensic toxicology, and polydrug consumption.

Conclusion Illicit use, initiation of therapy, and opioid use in combination with other psychoactive medications are contexts most clearly associated with impairment of driving-related functions and/or operation of a motor vehicle. Clinicians should counsel patients on the risk of impairment when initiating therapy, when co-prescribing opioids and other psychoactive drugs, or when a patient is suspected of having an opioid use disorder.
\end{abstract}

Keywords Opioid · Driving $\cdot$ Impairment $\cdot$ Psychomotor $\cdot$ Vigilance

\section{Introduction}

Impaired driving occurs when a vehicle operator is unable to appropriately respond to environmental stimuli due to aberrations in psychomotor function. Impaired driving represents a serious public health issue with various causes, ranging from sleep deprivation to intoxication. The CDC estimates that 4.2 million US adults drive under the influence of alcohol over the course of an average month, which translates to approximately 121 million events per year with significant crash risk from alcohol alone [1]. The USA is currently in an opioid epidemic, resulting in an increased number of individuals taking psychoactive drugs while executing the tasks of everyday life, including operating a motor vehicle. Opioids are a widely prescribed class of drug of both natural and synthetic origin. They are

Supervising Editor: Michael Hodgman, MD

Albert Conicella

albert.conicella@umassmemorial.org

1 Division of Medical Toxicology, Department of Emergency Medicine, University of Massachusetts Medical School, 55 Lake Avenue North, Worcester, MA 01655, USA primarily used clinically for their ability to produce analgesia by acting as agonists on opioid receptors located throughout the body, though are recognized to produce sedation as well [2].

A number of opioid receptor subtypes exist, all of which play important roles in normal physiology and are stimulated by endogenous compounds called "endorphins," named for their chemical similarity to morphine. Three opioid receptor subtypes, mu, delta, and kappa, have been best studied and are considered to be responsible for the majority of clinically relevant effects of opioid drugs. Mu opioid receptors are primarily located in the brainstem and medial thalamus and are responsible for modulating the analgesic effects of opioids. Mu receptor agonism produces supraspinal analgesia, respiratory depression, euphoria, sedation, decreased GI motility, and physical dependence [3,4]. Delta receptors are thought to play an important role in the analgesic function of opioids as well, though to a lesser degree than mu receptors, and have been suggested to have psychotomimetic, anxiolytic, and anti-depressant effects as well [3, 4]. Kappa receptor primary agonism leads to spinal analgesia, sedation, dyspnea, dependence, dysphoria, and respiratory depression. [3, 4]. Generally, opioids produce their effects through a hyperpolarization mechanism. As a result of 
receptor binding, voltage-dependent calcium inflow into the cell is impaired, which in turn prevents neurotransmitter release into the synapse. Opioids are mainly metabolized in the liver via the CYP enzymes, and some opioids have metabolites active at opioid receptors, complicating the relationship between opioid pharmacology and the ease of defining the time point at which an individual may be considered to no longer be experiencing the effects of opioid drugs. For example, heroin is metabolized into 6 -monoacetylmorphine (6-MAM), 3 monoacetylmorphine (3-MAM), and morphine, all of which have agonist activity at the mu receptor and variable half-lives [5]. The specific mechanisms and areas of the nervous system that may be involved in changes in psychomotor function secondary to opioid consumption have yet to be well categorized, though the major risks in operating a motor vehicle while consuming opioid drugs are considered to stem from their ability to produce sedation and cognitive impairment.

This review of the experimental, epidemiological, and forensic literature suggests a complicated picture in which the ability to operate a motor vehicle safely while taking opioid drugs may depend on the context of consumption, for example: if opioid consumption is illicit, if opioid drug therapy has been recently initiated, or if individuals take other psychoactive drugs in addition to opioids, among other variables.

\section{Methods}

A search of the literature was conducted using the following search terms: psychomotor impairment OR neurocognitive impairment OR psychomotor function OR neurocognitive function OR crash OR accident AND opioid OR opiate AND driving. Similar terms have been used in other reviews examining impaired driving and the included terms are believed to represent the various components that make up the driving-related processes, related opioid drug physiology, and public health risks. Articles were deemed eligible if published between October 1, 1992 through August 31, 2018. Databases included in the literature search include: PUBMED, which returned 157 hits and GOOGLE SCHOLAR which returned 9230 hits. The first 500 hits ordered by "most relevant" were evaluated after which the number of relevant manuscripts approached zero. Book chapters, non-peer reviewed publications, and expert opinions were excluded along with papers focusing on unique clinical contexts (e.g., hospice, end of life cancer care, medication assisted treatment for opioid use disorder), and those with concerning conflicts of interest. Studies examining dextromethorphan, a compound defined as an opioid agonist, though lacking clinically relevant action at the $\mathrm{Mu}$ receptor, were excluded from the review. A total of 84 papers were selected for inclusion based on their relevance to the question, "Does opioid drug use cause impairment relevant to the operation of a motor vehicle?" The publications included in this review include a sampling of experimental studies, forensic toxicology reports, and others. The review is divided into sections: (1) Experimental Administration, (2) Illicit Use, (3) Prescription use, (4) Forensic Toxicology, and (5) Polydrug Use. Each section compares studies of similar focus and synthesizes conclusions about what the data from that set of manuscripts suggests about the impact of opioid drugs on driving performance. The review closes with a summative interpretation and contextualization of the implications of the trends observed. The data presented in each paper is best understood as an individual puzzle piece which contributes to a holistic and contextual understanding of the psychomotor effects and risks associated with the use of opioid drugs.

\section{Results}

A total of 84 papers published between 1992 and 2018 met our eligiblity criteria for inclusion.

\section{Experimental Administration}

The 29 manuscripts included in this section (Table 1) generally examine the effects of opioid drugs as they are administered in a controlled experimental setting to volunteers. Manuscripts that support the conclusion that opioid drugs cause psychomotor impairment are indicated in red. Studies that fail to draw clear conclusions are noted in yellow, and studies that show no significant impact of opioid drugs on driving or driving-related neurocognitive function are noted in green. Twenty studies were determined to support the conclusion that opioid drugs cause psychomotor impairment, two studies failed to draw clear conclusions, and seven studies showed no significant impact of opioids on driving or driving-related neurocognitive function. The aims, findings, and notable strengths and weaknesses are noted for each citation.

\section{Illicit Use}

The six manuscripts included in this section (Table 2) relate to the illicit use of opioid drugs as opposed to the prescription use of opioid drugs. Manuscripts that support the conclusion that opioid drugs cause psychomotor impairment are indicated in red. Studies that fail to draw clear conclusions are noted in yellow, and studies that show no significant impact of opioid drugs on driving or driving-related neurocognitive function are noted in green. Six studies were determined to support the conclusion that opioid drugs cause psychomotor impairment, 0 studies failed to draw clear conclusions, and 0 studies showed no significant impact of opioids on driving or driving- 


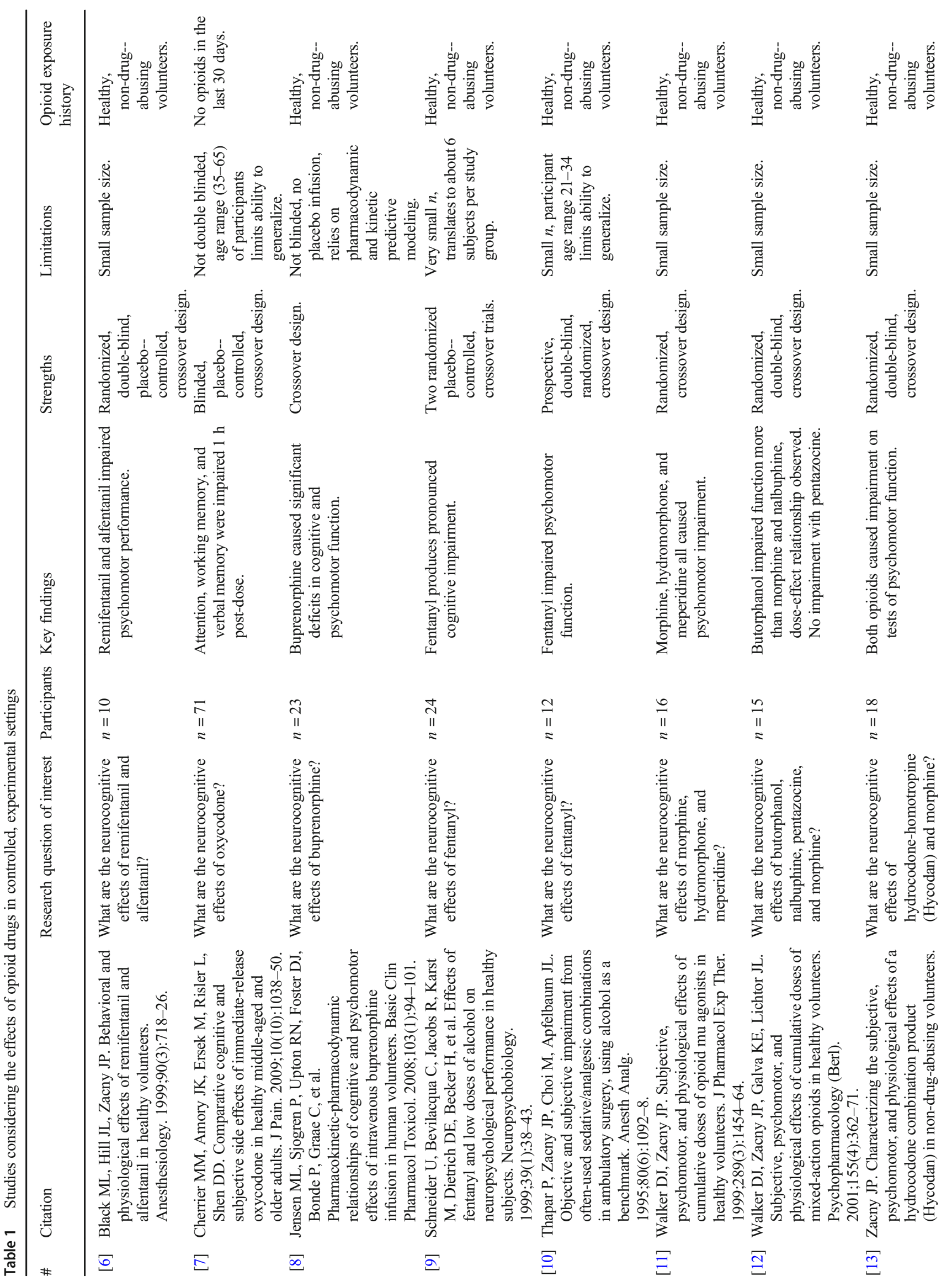




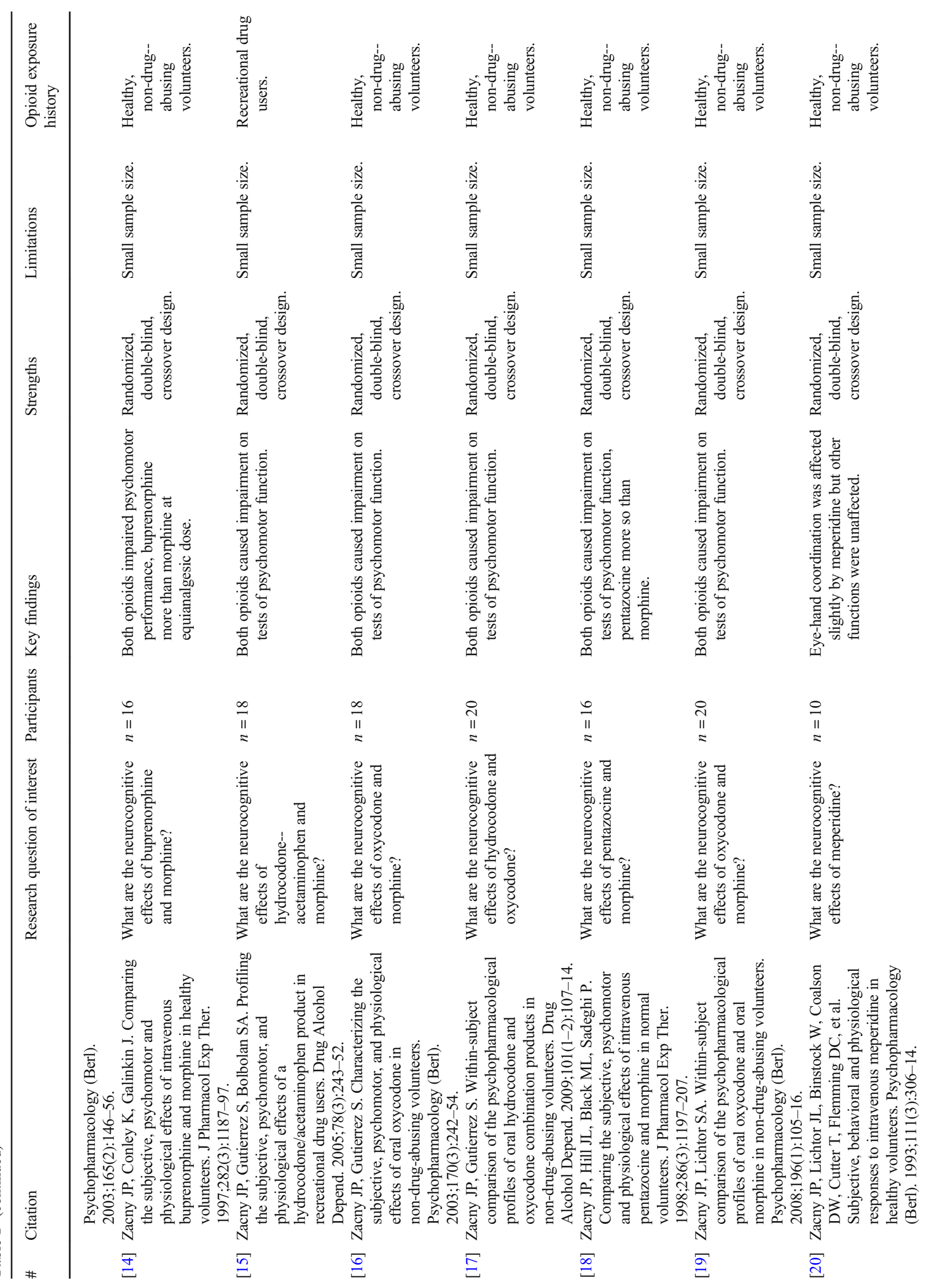




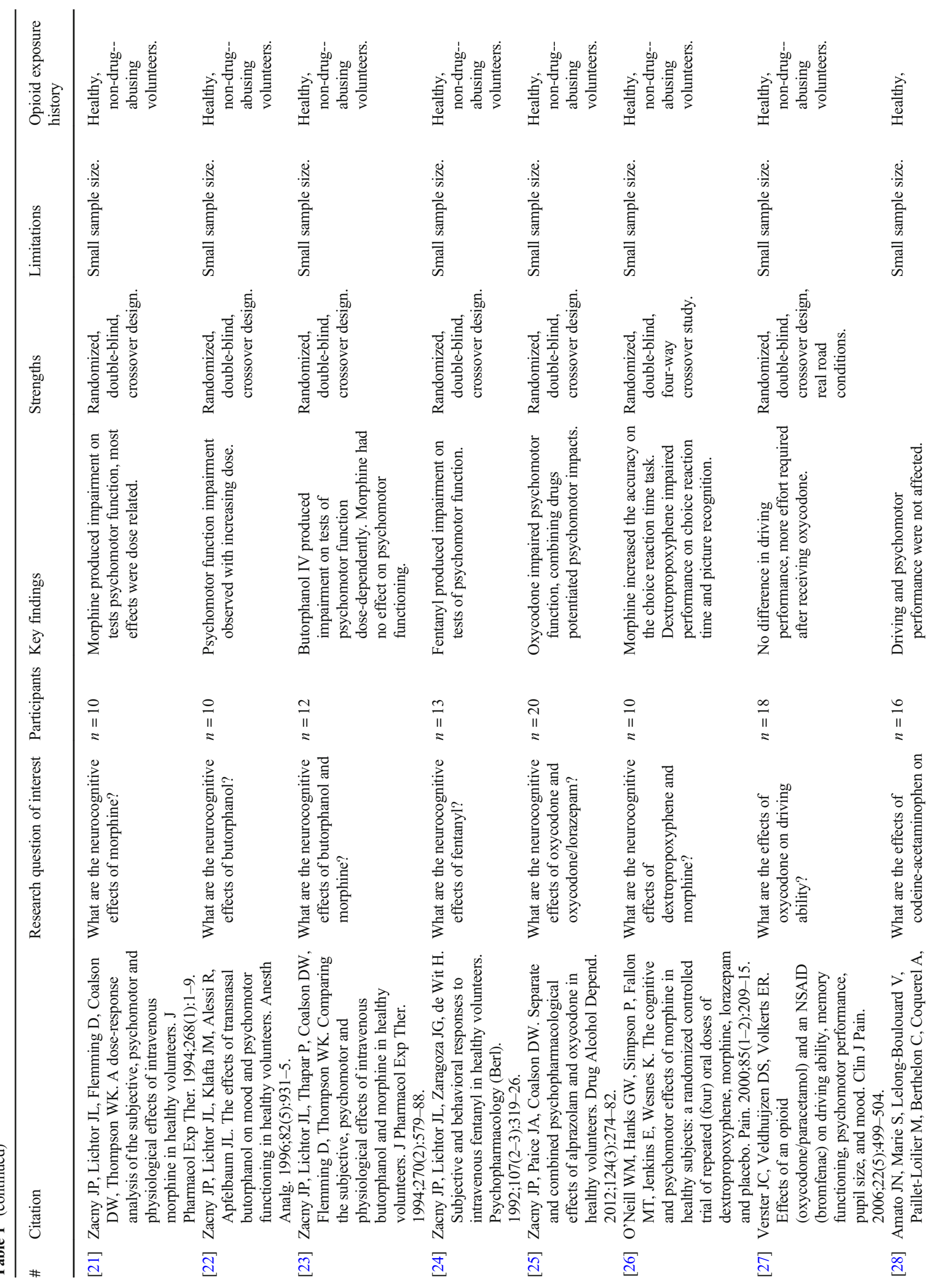




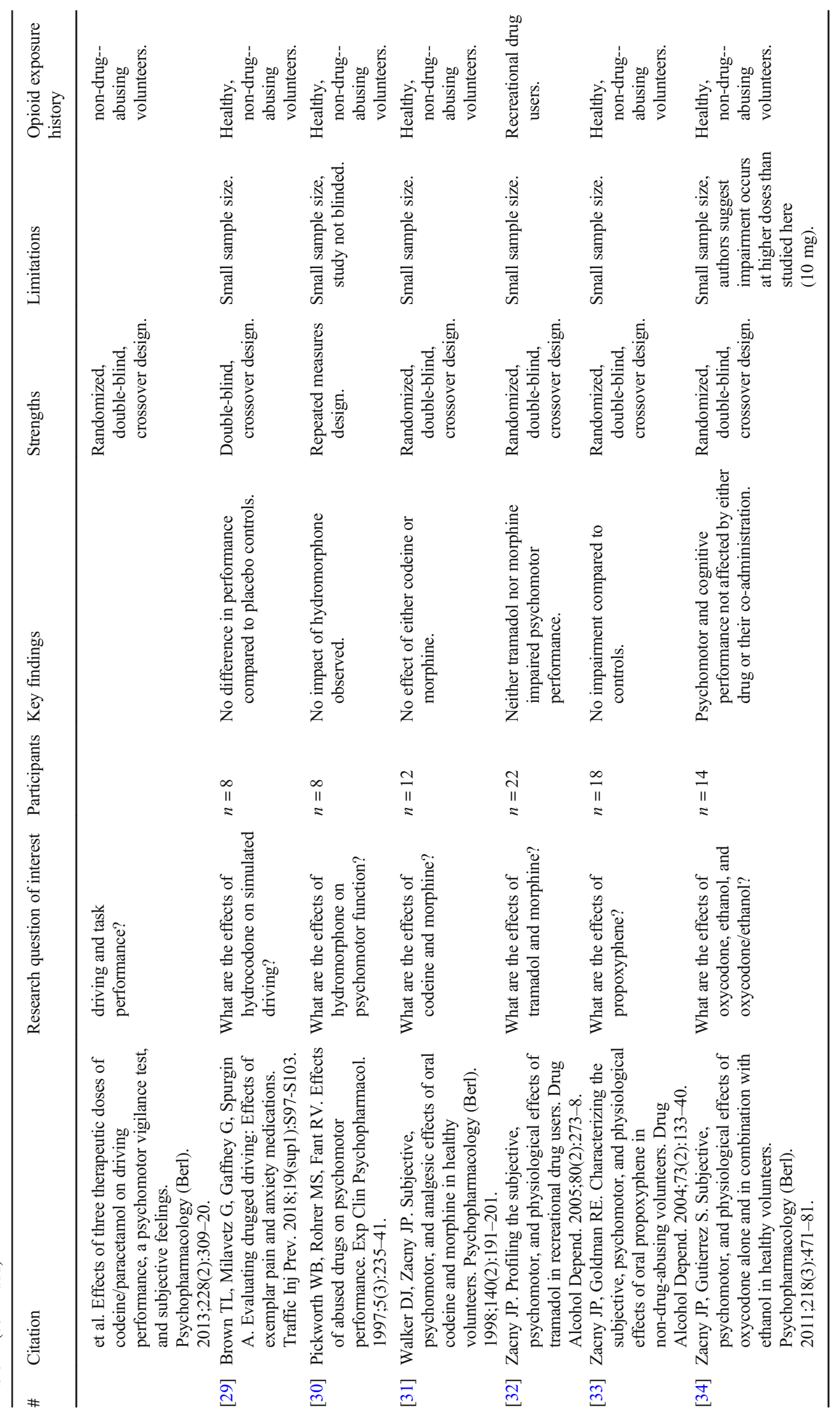


Table 2 Studies considering the effects of opioid drugs in the context of illicit consumption

Number Citation $\quad$ Research question of Participants Key findings Strengths Limitations

interest

\begin{tabular}{|c|c|c|c|c|c|c|}
\hline [35] & $\begin{array}{l}\text { Asbridge M, Cartwright } \\
\text { J, Langille D. Driving } \\
\text { under the influence of } \\
\text { opioids among high } \\
\text { school students in } \\
\text { Atlantic Canada: } \\
\text { prevalence, correlates, } \\
\text { and the role of medical }\end{array}$ & $\begin{array}{l}\text { What risk factors are } \\
\text { associated with } \\
\text { driving under the } \\
\text { influence of } \\
\text { opioids? }\end{array}$ & $n=3655$ & $\begin{array}{l}\text { Increased incidence of } \\
\text { driving under the } \\
\text { influence among those } \\
\text { consuming opioids } \\
\text { both recreationally and } \\
\text { medically (25.1\%) } \\
\text { compared to those } \\
\text { with exclusive medical }\end{array}$ & $\begin{array}{l}\text { Anonymous data } \\
\text { collection, large } \\
\text { sample size, age } \\
\text { matched controls. }\end{array}$ & $\begin{array}{l}\text { Limited } \\
\text { generalizability as } \\
\text { only considered high } \\
\text { school students, } \\
\text { survey methodology } \\
\text { subject to reporting } \\
\text { bias. }\end{array}$ \\
\hline
\end{tabular}

versus recreational

consumption. Accid

Anal Prev.

2015;75:184-91.

[36] Bachs L, Hoiseth G,

[37] Bassiony MM, Youssef
UM, Hassan MS,

[38] Ceder G, Jones AW.

[40] Wang GY, Wouldes TA,
Kydd R, Jensen M,

Skurtveit S, Morland

J. Heroin-using

drivers: importance of

morphine and

morphine-6--

glucuronide on late

clinical impairment.

Eur J Clin Pharmacol.

2006;62(11):905-12.

Salah El-Deen GM,

El-Gohari H,

Abdelghani M, et al.

Cognitive Impairment

and Tramadol

Dependence. J Clin

Psychopharmacol.

2017;37(1):61-6.

Concentration ratios

of morphine to

codeine in blood of

impaired drivers as

evidence of heroin use

and not medication

with codeine. Clin

Chem.

2001;47(11):1980-4.

[39] Jones AW, Holmgren A, Are opioids identified $n=2573$

Kugelberg FC.

Driving under the

influence of opiates:

concentration

relationships between

morphine, codeine,

6-acetyl morphine,

and ethyl morphine in

blood. J Anal Toxicol.

2008;32(4):265-72.

Russell BR.

Neuropsychological

What is the

relationship

between major

heroin metabolites

and psychomotor

function?

What is the

cognitive

impairment among

tramadol-abuse

patients?

Which opioids and/or $n=979$ opioid metabolites

are observed in

blood samples of

drivers suspected

of impairment?

in body fluid

samples of

impaired drivers

from prescription

opioid use or illicit

heroin use?

performance of

methadone--

maintained opiate

users. J

Are there differences in neurocognitive performance between individuals taking methadone, illicit opioid users, and $n=100$,

control

$\mathrm{n}=100$

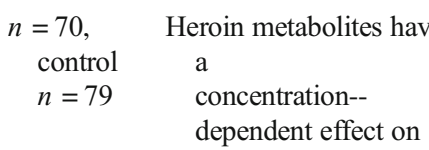

$n=70$,

control

$n=79$

a

concentration--

dependent effect on

the CNS that may lead

to impairment.

Tramadol-abuse patients were more than twice as likely to show cognitive impairment as control subjects.

$85 \%$ of opiate-positive blood samples were from heroin use rather than prescription opioids. prevalence of

Attempts to control for

Quantitative data, large

Approximately $90 \%$ of apprehended drivers in Sweden with morphine and codeine in their blood had used heroin.
Methadone Controls preformed $n=32$,

illicit opioids $n=17$, controls $\mathrm{n}=25$ slightly better than methadone patients on 3 psychomotor tasks, illicit opioid users preformed significantly worse than controls on tests
Quantitative data, design allows isolation of opioid agonist effect vs. impact of substance abuse.
High proportion of men in sample, younger people overrepresented. polysubstance abuse in the

tramadol-abuse

group, uses Montreal Cognitive

Assessment which is

a well-studied

cognitive test. sample size.

Data shows negative cognitive effect may be limited to memory without comparable affects detected in other cognitive domains, limited sample size.

\section{Possibility of} prescription morphine use cannot be completed excluded due to reliance on morphine/codeine unity ratios.

Large population, longitudinal design.

Inconsistency in fluid sampling protocol, possibility of prescription morphine use cannot be completed excluded due to reliance on morphine/codeine unity ratios.

Small sample size. 
Table 2 (continued)

\begin{tabular}{cllll}
\hline Number Citation & $\begin{array}{l}\text { Research question of } \\
\text { interest }\end{array}$ & Participants & Key findings & Limitations \\
\hline $\begin{array}{l}\text { Psychopharmacol. } \\
\text { 2014;28(8):789-99. }\end{array}$ & $\begin{array}{l}\text { non-opioid } \\
\text { controls? }\end{array}$ & $\begin{array}{l}\text { of attention and } \\
\text { executive function. }\end{array}$ & \\
\hline
\end{tabular}

related neurocognitive function. The aims, findings, and notable strengths and weaknesses are noted for each citation.

\section{Prescription Use}

The 29 manuscripts included in this section (Table 3 ) focus on prescription use of opioid drugs as opposed to recreational use of opioid drugs. Manuscripts that support the conclusion that opioid drugs cause psychomotor impairment are indicated in red. Studies that fail to draw clear conclusions are noted in yellow, and studies that show no significant impact of opioid drugs on driving or driving-related neurocognitive function are noted in green. Fifteen studies were determined to support the conclusion that opioid drugs cause psychomotor impairment, 4 studies failed to draw clear conclusions, and 10 studies showed no significant impact of opioids on driving or driving-related neurocognitive function. The aims, findings, and notable strengths and weaknesses are noted for each citation.

\section{Forensic Toxicology}

The 13 manuscripts included in this section (Table 4) include studies that explore the relationship between opioid drug use and the risk of unsafe driving action, obtaining an injury, or being in a fatal accident. Manuscripts that support the conclusion that opioid drugs cause psychomotor impairment are indicated in red. Studies that fail to draw clear conclusions are noted in yellow, and studies that show no significant impact of opioid drugs on driving or driving-related neurocognitive function are noted in green. Nine studies were determined to support the conclusion that opioid drugs cause psychomotor impairment, two studies failed to draw clear conclusions, and two studies showed no significant impact of opioids on driving or driving-related neurocognitive function. The aims, findings, and notable strengths and weaknesses are noted for each citation.

\section{Polydrug Use}

The seven manuscripts included in this section (Table 5) generally relate to studies that explore the important role of polydrug use in populations who consume opioid drugs. These manuscripts generally fail to draw conclusions about the impact of opioid drugs and psychomotor performance due to high rates of polydrug use in the populations considered. These manuscripts are noted by a neutral color, blue. The aims, findings, and notable strengths and weaknesses are noted for each citation.

\section{Discussion}

The majority of articles in the Experimental Administration section indicate opioids generally impair psychomotor function in volunteers without a history of opioid use. Sixty-nine percent of studies support the conclusion that opioids impair driving or driving-related neurocognitive performance. While many studies were inconclusive or showed no effect, the majority of studies support the conclusion that opioids cause neurocognitive impairment. This suggests a baseline risk associated with the use of opioids and complex psychomotor activities, such as driving. There is evidence to suggest a dose-response relationship between opioid drug therapy and impairment as well. This conclusion is in accord with what is known about the hyperpolarization mechanism of action of opioid drugs on neurons in the central nervous system producing impairment in memory, decision making, and coordination. However, not all data supports the conclusion that opioids impair performance, which conflicts with what is known about the hyperpolarization mechanism of action of opioids. There are a number of possibilities which may explain the variation in the data including selection bias (e.g., administration in a population of drug users vs. naive volunteers), small sample size increasing vulnerability to Type II error, and the experimental administration of opioids at doses insufficient to produce impairment. The majority of studies in this section have a small sample size and are vulnerable to the influence of outlying data points and confounding variables.

All of the studies considered in the "Illicit Use" section generally favor the conclusion that the consumption of opioid drugs in the settings and populations considered is associated with unsafe driving, neurocognitive impairment, and/or arrest. When considering which populations and individuals may be considered to be at higher risk for poor outcome when using opioids and driving, those doing so illicitly merit particular concern. However, young people and men were often overrepresented in the populations included in the studies in this 
Table 3 Studies considering the effects of prescribed opioid drugs

\begin{tabular}{llllll}
\hline Number Citation & $\begin{array}{l}\text { Research question of } \\
\text { interest }\end{array}$ & Participants & Key findings & Strengths & Limitations
\end{tabular}

\begin{tabular}{|c|c|c|c|c|c|c|}
\hline [41] & $\begin{array}{l}\text { Buckeridge D, Huang A, } \\
\text { Hanley J, Kelome A, } \\
\text { Reidel K, Verma A, et al. } \\
\text { Risk of injury associated } \\
\text { with opioid use in older } \\
\text { adults. J Am Geriatr Soc. } \\
\text { 2010;58(9):1664-70. }\end{array}$ & $\begin{array}{l}\text { Is there a dose-response } \\
\text { relationship between } \\
\text { opioid dose and } \\
\text { injury? }\end{array}$ & $n=403,339$ & $\begin{array}{l}\text { Opioids found to } \\
\text { increase risk of } \\
\text { injury, codeine } \\
\text { combinations } \\
\text { showed highest risk, } \\
\text { no dose relationship } \\
\text { observed. }\end{array}$ & $\begin{array}{l}\text { Large sample } \\
\text { size. }\end{array}$ & $\begin{array}{l}\text { Only considered those } \\
\text { aged } 65 \text { and older, } \\
\text { limits } \\
\text { generalizability. }\end{array}$ \\
\hline [42] & $\begin{array}{l}\text { Engeland A, Skurtveit S, } \\
\text { Morland J. Risk of road } \\
\text { traffic accidents } \\
\text { associated with the } \\
\text { prescription of drugs: a }\end{array}$ & $\begin{array}{l}\text { What is the crash risk in } \\
\text { the time period after } \\
\text { filling a prescription } \\
\text { for a psychoactive } \\
\text { drug? }\end{array}$ & $\begin{array}{l}\text { Accidents } \\
\quad n=13,000\end{array}$ & $\begin{array}{l}\text { 2x more likely to be in } \\
\text { accident if taking a } \\
\text { natural opium } \\
\text { alkaloid. }\end{array}$ & $\begin{array}{l}\text { Large sample } \\
\text { size, good } \\
\text { generalizabili- } \\
\text { ty. }\end{array}$ & $\begin{array}{l}\text { Only considers } \\
\text { accident risk in first } \\
7 \text { days after } \\
\text { prescription } \\
\text { dispensed. }\end{array}$ \\
\hline
\end{tabular}

[43] French DD, Campbell R, Spehar A, Cunningham F, Bulat T, Luther SL. Drugs and falls in community-dwelling older people: a national veterans study. Clin Ther. 2006;28(4):619-30.

[44] Gibson JE, Hubbard RB, Smith CJ, Tata LJ, Britton JR, Fogarty AW. Use of self-controlled analytical techniques to assess the association between use of prescription medications and the risk of motor vehicle crashes. Am J Epidemiol. 2009;169(6):761-8.

[45] Gomes T, Redelmeier DA, Juurlink DN, Dhalla IA, Camacho X, Mamdani MM. Opioid dose and risk of road trauma in Canada: a population-based study. JAMA Intern Med. 2013;173(3):196-201.

[46] Karjalainen K, Haukka J, Lintonen T, Joukamaa M, Lillsunde P. The use of psychoactive prescription drugs among DUI suspects. Drug Alcohol Depend. 2015;155:215-21.

[47] Leveille SG, Buchner DM, Koepsell TD, McCloskey LW, Wolf ME, Wagner EH. Psychoactive medications and injurious motor vehicle collisions involving

\author{
What psychoactive \\ medications are \\ associated with \\ increased fall risk in \\ the year after \\ prescription?

$$
\begin{aligned}
n= & 20,551 \\
& \text { control } \\
& n=20,551
\end{aligned}
$$
What is the relationship accidents between having a $\quad n=49,821$ certain drug prescription and crash risk?
Increased fall incidence in groups taking prescribed opioid drugs.
Retrospective, cross-sectional national sample, age and sex-matched controls.

(1)

\section{Large sample size, good generalizabili- ty.} opioid/acetaminophen combination.
Methods cannot distinguish between effect of event triggering opioid $\mathrm{Rx}$ (frequently MVC) and intrinsic opioid drug effect.$$
\text { drug effect. }
$$

Limited to veterans care network and elderly population which limits generalizability.

$\begin{array}{lccc}\begin{array}{l}\text { Is there a relationship } \\ \text { between prescription } \\ \text { opioid dose and the }\end{array} & \begin{array}{c}n=5300, \\ \text { control }\end{array} & \begin{array}{c}\text { Significant relationship } \\ \text { between drug dose } \\ \text { likelihood of }\end{array} & \begin{array}{l}\text { Controls } \\ \text { matched for }\end{array} \\ \text { involvement in road } & & \text { trauma to driver. } & \begin{array}{l}\text { age, sex, prior } \\ \text { trauma, and } \\ \text { disease risk }\end{array} \\ \text { trauma? } & & & \begin{array}{l}\text { index. } \\ \text { ind }\end{array}\end{array}$

What psychoactive medications are associated with increased risk of driving under the influence (DUI)?

Are psychoactive medications associated with increased injurious crash risk?
DUI suspect $n=29,470$, control $n=30,043$
DUI suspects had increased odds of having purchased an opioid prescription than controls.
Large sample size, age and sex-matched controls.
$n=234$, control $88 \%$ increased risk of Age and crash in older drivers taking opioids.

Case population visited the ED more frequently, notably for alcohol related complaints, on average than control population.
Population level differences in prescribing of opioid drugs by gender.
Limited to age 65 or above who sought care after a motor vehicle collision. Socioeconomics, medical comorbidities risk factors for crash.


Table 3 (continued)

\begin{tabular}{llllll}
\hline Number Citation & $\begin{array}{l}\text { Research question of } \\
\text { interest }\end{array}$ & Participants & Key findings & Strengths & Limitations
\end{tabular}

older drivers.

Epidemiology. 1994;5(6):591-8.

[48] Marco CA, Mann D, Rasp

J, Ballester M, Perkins

O, Holbrook MB, et al.

Effects of opioid

medications on cognitive

skills among Emergency

Department patients. Am

J Emerg Med.

2018;36(6):1009-13.

[49] Meuleners LB, Duke J, Lee

AH, Palamara $P$,

Hildebrand J, Ng JQ.

Psychoactive

medications and crash

involvement requiring

hospitalization for older

drivers: a

population-based study.

J Am Geriatr Soc.

2011;59(9):1575-80.

[50] Monarrez-Espino J,

Laflamme L, Rausch C,

Elling B, Moller J. New

opioid analgesic use and

the risk of injurious

single-vehicle crashes in

drivers aged

50-80 years: A

population-based

matched case-control

study. Age Aging.

2016;45(5):628-34.

[51] Rudisill TM, Zhu M,

Davidov D, Leann Long

D, Sambamoorthi U,

Abate M, et al.

Medication use and the

risk of motor vehicle

collision in West

Virginia drivers 65 years

of age and older: a

case-crossover study.

BMC Res Notes.

2016;9:166.

[52] Schiltenwolf M, Akbar M, How does the

Hug A, Pfuller U, Gantz

$\mathrm{S}$, Neubauer E, et al.

Evidence of specific cognitive deficits in patients with chronic low back pain under long-term substitution treatment of opioids.

Pain Physician. 2014;

17(1):9-20.

[53] Shorr RI, Griffin MR,

Daugherty JR, Ray WA.

Opioid analgesics and
What are the

neurocognitive

effects of opioids

given for acute pain?

Emergency
department
pain patients
$n=65$

Mean mini-mental
status exam scores
decreased 1 point
after taking opioids,
a greater proportion
of tests administered
were abnormal after
opioids.

Is there an association $\quad n=1616$

between

psychoactive

medication

prescription and

crash risk?

Is there a relationship

between opioid

prescription and

injurious crash risk?

crash $n=4445$,

control

$n=17,780$

$50 \%$ greater risk of

being in a crash

requiring

hospitalization was

found for people

prescribed opioids.
Uses

well-studied

tests of

neurocogniti-

ve function,

crossover

design.

Retrospective, crossover study
Small effect size, 35\% were considered cognitively impaired at baseline.

Only considers drivers over 60 , limiting generalizability.

\section{Which prescription drugs are associated with increased risk of injurious crash?

\author{
crash $n=611 \quad$ Tramadol was \\ associated with \\ increased odds of \\ injurious crash.
} Large sample
size, crossover
design.

\section{neurocognitive \\ pain/chronic}

performance of

chronic pain patients

receiving chronic

opioid therapy

compare to controls?

Chronic back

opioids

$n=37$,

chronic back

pain without

opioids

$n=33$,

control

$n=25$
Is the risk of hip
fracture associated
with codeine or

$$
\begin{aligned}
& \text { patient } \\
& n=4500,
\end{aligned}
$$

Both pain subgroups preformed worse than controls, opioid patients preformed worse than non-opioid patients and pain-free

controls.

Explores influence of pain and depression on neurocognitive performance.
Only considers drivers aged 50-80, limits generalizability.
Only considers drivers over the age of 65 , limiting generalizability.


Table 3 (continued)

\begin{tabular}{|c|c|c|c|c|c|c|}
\hline Number & Citation & $\begin{array}{l}\text { Research question of } \\
\text { interest }\end{array}$ & Participants & Key findings & Strengths & Limitations \\
\hline & $\begin{array}{l}\text { the risk of hip fracture in } \\
\text { the elderly: codeine and } \\
\text { propoxyphene. J } \\
\text { Gerontol. } \\
\text { 1992;47(4):M111-5. }\end{array}$ & $\begin{array}{l}\text { propoxyphene } \\
\text { prescription? }\end{array}$ & $\begin{array}{l}\text { control } \\
n=24,041\end{array}$ & $\begin{array}{l}\text { prescription. In new } \\
\text { users, significantly } \\
\text { increased relative } \\
\text { risk of fracture (2.2) } \\
\text { compared to users } \\
\text { with prescription } \\
\text { history (1.3). }\end{array}$ & $\begin{array}{l}\text { well-matched } \\
\text { controls. }\end{array}$ & $\begin{array}{l}\text { limiting } \\
\text { generalizability. }\end{array}$ \\
\hline [54] & $\begin{array}{l}\text { Sjogren } \mathrm{P} \text {, Thomsen AB, } \\
\text { Olsen AK. Impaired } \\
\text { neuropsychological } \\
\text { performance in chronic } \\
\text { nonmalignant pain } \\
\text { patients receiving }\end{array}$ & $\begin{array}{l}\text { How does the } \\
\text { neurocognitive } \\
\text { performance of } \\
\text { chronic pain patients } \\
\text { receiving chronic } \\
\text { opioid therapy }\end{array}$ & $\begin{array}{l}\text { Patient } n=40 \text {, } \\
\quad \text { control } \\
\quad n=40\end{array}$ & $\begin{array}{l}\text { Pain patients receiving } \\
\text { chronic opioid } \\
\text { therapy performed } \\
\text { significantly poorer } \\
\text { than controls. }\end{array}$ & $\begin{array}{l}\text { Controlled, } \\
\text { experimental } \\
\text { setting. }\end{array}$ & $\begin{array}{l}\text { Comparison group did } \\
\text { not have pain at } \\
\text { baseline, unable to } \\
\text { separate effect of } \\
\text { opioids and effect of } \\
\text { pain. }\end{array}$ \\
\hline
\end{tabular}

long-term oral opioid compare to controls?

therapy. J Pain Symptom

Manage.

2000;19(2):100-8.

[55] Soderberg KC, Laflamme

L, Moller J. Newly

initiated opioid treatment

and the risk of

fall-related injuries. A

nationwide,

register-based,

case-crossover study in

Sweden. CNS Drugs.

2013;27(2):155-61.

[56] Jamison RN, Schein JR,

Vallow S, Ascher S,

Vorsanger GJ, Katz NP.

Neuropsychological

effects of long-term

opioid use in chronic

pain patients. J Pain

Symptom Manage.

2003;26(4):913-21.

[57] Sabatowski R, Scharnagel

R, Gyllensvard A,

Steigerwald I. Driving

Ability in Patients with

Severe Chronic Low

Back or Osteoarthritis

Knee Pain on Stable

Treatment with

Tapentadol Prolonged

Release: A Multicenter,

Open-label, Phase 3b

Trial. Pain Ther.

2014;3(1):17-29.

[58] Schumacher MB, Jongen S, What impact does

Knoche A, Petzke F,

Vuurman EF, Vollrath

M, et al. Effect of

Is there an increased

risk of injurious fall

after receiving an

opioid prescription?

Injurious fall Increased risk on

$n=167,257$

injurious fall with

new opioid

prescription,

increased odds of

injury in the days

after filling

prescription

compared to

4 weeks later.

How do chronic $\quad n=44$

opioids in chronic

non-cancer pain

patients affect

neurocognitive

performance over

time?

What effect does

tapentadol have on

driving performance

after 6 weeks of

stable dosing in

chronic non-cancer

pain patients?

$$
n=35
$$

Test scores

significantly improved while subjects were taking opioids for pain compared to when they were not.

$66 \%$ of patients were classified as fit to drive at doses $>200 \mathrm{mg} /$ day, doses $<200 \mathrm{mg} /$ day did not impair performance.
Large sample Increased odds ratio of size, crossover injury if between design the ages of 18 and 29 (7.17), age is a possible confounding variable.

\begin{tabular}{|c|c|}
\hline $\begin{array}{l}\text { Crossover } \\
\text { design, decent } \\
\text { sample size }\end{array}$ & $\begin{array}{l}\text { No control group, } \\
\text { results demonstrate } \\
\text { psychomotor } \\
\text { impact of untreated } \\
\text { pain more than } \\
\text { effect of opioids, } \\
\text { only two } \\
\text { psychomotor tests } \\
\text { were administered } \\
\text { Small sample size, } \\
\text { potentially } \\
\text { non-generalizable } \\
\text { cut-off dose for } \\
\text { analysis, pain } \\
\text { possible } \\
\text { confounding } \\
\text { variable. }\end{array}$ \\
\hline
\end{tabular}
chronic opioid therapy on actual driving performance in non-cancer pain patients. Psychopharmacology (Berl). 2017;234(6):989-99. chronic opioid therapy have on driving task performance in chronic non-cancer pain patients?

\author{
$n=20$, control Driving performance \\ $n=19$ \\ did not significantly \\ differ from that of \\ controls due to \\ inter-individual \\ variations.
}

Standardized, Small sample size. on-the-road driving tests in normal traffic. 
Table 3 (continued)

\begin{tabular}{llllll}
\hline Number Citation & $\begin{array}{l}\text { Research question of } \\
\text { interest }\end{array}$ & Participants & Key findings & Strengths & Limitations
\end{tabular}

[59] Strumpf M,

Willweber-Strumpf A, Herberg KW, Zenz M. [Safety-relevant performance of patients on chronic opioid therapy]. Schmerz. 2005;19(5):426-33.

[60] Byas-Smith MG, Chapman SL, Reed B, Cotsonis G. The effect of opioids on driving and psychomotor performance in patients with chronic pain. Clin J Pain.

2005;21(4):345-52.

[61] Dagtekin O, Gerbershagen HJ, Wagner W, Petzke F, Radbruch L, Sabatowski R. Assessing cognitive and psychomotor performance under long-term treatment with transdermal buprenorphine in chronic non-cancer pain patients. Anesth Analg. 2007;105(5):1442-8, table of contents.

[62] Gaertner J, Radbruch L, Giesecke T,

Gerbershagen H, Petzke

$\mathrm{F}$, Ostgathe C, et al.

Assessing cognition and psychomotor function under long-term treatment with controlled release oxycodone in non-cancer pain patients. Acta Anaesthesiol Scand. 2006;50(6):664-72.

[63] Hooper TI, DeBakey SF, Pearse L, Pratt S, Hoffman KJ. The use of electronic pharmacy data to investigate prescribed medications and fatal motor vehicle crashes in a military population, 2002-2006. Accid Anal Prev. 2010;42(1):261-8.

[64] Krebs EE, Paudel M, Taylor BC, Bauer DC, Fink HA, Lane NE, et al. Association of Opioids with Falls, Fractures, and Physical Performance among Older Men with Persistent
Is there a difference in $n=80$, control Significant variability psychomotor $\quad n=243 \quad$ in data, effects of performance opioid drugs may be between patients on chronic opioid therapy and controls?

What differences in psychomotor task performance and driving performance between patients with chronic pain on opioids and controls?

$\begin{array}{ll}n=21, \text { control } & \text { No significant } \\ n=11 & \text { differences were } \\ & \text { found on driving } \\ & \text { performance or } \\ & \text { neuro/psychomotor } \\ & \text { function. }\end{array}$

Driving evaluated directly by in-car task performance including turning and parallel parking.

What is the effect of chronic transdermal buprenorphine on driving performance in patients with chronic nonmalignant pain?

$\begin{array}{ccc}n=30, \text { control } & \text { Patients receiving } & \text { Quantitative } \\ n=90 & \text { transdermal } & \text { data, matched } \\ & \text { buprenorphine did } & \text { pairs. }\end{array}$
not perform inferiorly to controls.

What are the effects of $n=30$, control No difference in long-term treatment $n=90 \quad$ performance with oxycodone on driving performance?

\section{Multiple tests of Definition of performance, well-matched controls.

$$
\begin{aligned}
& \text { "non-inferior to } \\
& \text { control" defined as } \\
& \text { scoring above the } \\
& \text { 16th percentile on } \\
& \text { the standardized } \\
& \text { psychomotor tests } \\
& \text { lack rigor. }
\end{aligned}
$$
oxycodone and controls.

\section{Definition of "non-inferior to control" defined as scoring above the 16th percentile on the standardized psychomotor tests lack rigor.}

Small sample size, only considers patients on stable drug regimen.
What psychoactive medications are associated with increased risk of fatal

$$
\begin{array}{ccc}
n=962, \text { control } & \text { No associated increased } & \text { Well-matched } \\
n=2886 & \text { crash risk with } & \text { controls. } \\
& \text { opioid prescription. }
\end{array}
$$
crash?

Population is $93 \%$ male, all active duty military, limiting generalizability. Presence of medical comorbidity likely confounding variable affecting crash risk.

$\begin{array}{lllll}\text { Do chronic opioids } & \text { Population } & \text { No difference in fall } & \text { Large sample } & \text { Only considers those } \\ \text { affect fall risk, injury } & n=5994, & \text { risk, fractures, or } & \text { size, } & \text { aged } 65 \text { or greater, } \\ \text { risk, or physical } & \text { chronic } & \text { physical } & \text { prospective } & \text { limiting } \\ \text { performance? } & \text { opioid } & \text { performance in those } & \text { longitudinal } & \text { generalizability. } \\ & n=309 & \text { taking opioids. } & \text { cohort design. } & \end{array}$


Table 3 (continued)

Number Citation $\quad \begin{aligned} & \text { Research question of } \\ & \text { interest }\end{aligned}$ Participants $\quad$ Key findings $\quad$ Strengths $\quad$ Limitations

interest

Musculoskeletal Pain. J

Gen Intern Med.

2016;31(5):463-9.

[65] Menefee LA, Frank ED,

Crerand C, Jalali S, Park

$\mathrm{J}$, Sanschagrin K, et al.

The effects of

transdermal fentanyl on

driving, cognitive

performance, and

balance in patients with

chronic nonmalignant

pain conditions. Pain

Med. 2004;5(1):42-9.

[66] Nilsen HK, Landro NI,

Kaasa S, Jenssen GD,

Fayers P, Borchgrevink

PC. Driving functions in

a video simulator in

chronic nonmalignant

pain patients using and

not using codeine. Eur $\mathrm{J}$

Pain.

2011;15(4):409-15.

[67] Ray WA, Fought RL, Decker MD.

Psychoactive drugs and the risk of injurious motor vehicle crashes in elderly drivers. Am J

Epidemiol.

1992;136(7):873-83.

[68] Sabatowski R, Schwalen S, What are the effects of

Rettig K, Herberg KW,

Kasper SM, Radbruch L.

Driving ability under

long-term treatment with

transdermal fentanyl. J

Pain Symptom Manage. 2003;25(1):38-47.

[69] Tassain V, Attal N, Fletcher

D, Brasseur L, Degieux

$\mathrm{P}$, Chauvin M, et al.

Long-term effects of oral

sustained release

morphine on

neuropsychological

performance in patients

with chronic non-cancer

pain. Pain.

2003;104(1-2):389-400.

chronic non-cancer

pain patients already

on opioids impact

driving performance,

cognition, and/or

balance?

Do pain and/or codeine

influence

performance on a

driving simulator?

Is psychoactive drug

prescription

associated with risk

of injurious crash in

an elderly

population?

long-term treatment

with transdermal

fentanyl on complex

activities, such as

driving?

\begin{tabular}{|c|c|c|}
\hline $\begin{array}{l}\text { Does adding } \\
\text { transdermal fentanyl } \\
\text { to the regimen of }\end{array}$ & $n=23$ & $\begin{array}{l}\text { No negative impact of } \\
\text { adding transdermal } \\
\text { fentanyl. }\end{array}$ \\
\hline
\end{tabular}

$\begin{array}{cl}n=30, \text { control } & \text { Patients receiving } \\ \mathrm{n}=90 & \text { fentanyl did not } \\ & \text { perform inferiorly to }\end{array}$

hronic pain on Patients using codein

codeine driving performance

$n=20$,

from controls.

chronic pain

patients not

using

codeine

$n=20$,

control

$n=20$.

Population

$n=16,262$,

crash

$n=495$.

No significant

difference in relative

risk of injurious

crash in patients

taking opioid drugs.

Retrospective cohort design, age and health status matched controls.

Controlled

experimental

environment

Not able to distinguish effect of drug and effect of pain.

Participants on opioids at baseline, patients were given a month to stabilize on the fentanyl before performance retesting.

Only considers those aged 65 or greater, socioeconomic confounding variable as study only considered Medicaid recipients.

Well-matched controls, prospective study design.

Small sample size, 9 patients excluded due to contaminant drug abuse, so patient $n=21$.

$\begin{array}{cll}\text { Morphine } & \text { Patients receiving } & \text { Long-term } \\ n=18, & \text { morphine did not } & \text { prospective } \\ \text { control } & \text { perform inferiorly to } & \text { study, } \\ n=10 & \text { controls. } & 12 \text { months. }\end{array}$

Small sample size, control group consists of patients who started morphine and discontinued due to side effects. section. The overrepresentation of young people, for example, may bias the data as you people are more prone to risk-taking behavior. This suggests that factors intrinsic to the populations considered (e.g., age, sex) may modulate driving risk as it relates to opioid drugs to a significant degree. Further, this population is difficult to study due to the illegal status of opioid consumption, limiting the amount of studies present on the subject in the literature as well as their sample size and power.

Prescription use was not as clearly associated with increased or decreased risk, though more studies support the 
Table 4 Studies that use forensic toxicological methodology to draw conclusions

\begin{tabular}{llllll}
\hline Number Citation & $\begin{array}{l}\text { Research question of } \\
\text { interest }\end{array}$ & Participants & Key findings & Strengths & Limitations
\end{tabular}

\begin{tabular}{|c|c|c|c|c|c|c|}
\hline [70] & $\begin{array}{l}\text { Dubois S, Bedard M, } \\
\text { Weaver B. The } \\
\text { association between } \\
\text { opioid analgesics and } \\
\text { unsafe driving actions } \\
\text { preceding fatal crashes. } \\
\text { Accid Anal Prev. } \\
\text { 2010;42(1):30-7. }\end{array}$ & $\begin{array}{l}\text { Is positive opioid } \\
\text { toxicology associated } \\
\text { with committing an } \\
\text { unsafe driving action? }\end{array}$ & $n=2541$ & $\begin{array}{l}\text { Positive opioid } \\
\text { toxicology is } \\
\text { associated with } \\
\text { increased risk of } \\
\text { unsafe driving } \\
\text { action. }\end{array}$ & $\begin{array}{l}\text { Large sample } \\
\text { size. }\end{array}$ & $\begin{array}{l}\text { Effect only seen in certain } \\
\text { demographic groups, } \\
\text { specifically females aged } \\
25-55 \text { and males aged } \\
25-65, \text { suggests possi- } \\
\text { bility of confounding } \\
\text { variables. }\end{array}$ \\
\hline [71] & $\begin{array}{l}\text { Hamnett HJ, Ilett M, Izzati } \\
\text { F, Smith SS, Watson } \\
\text { KH. Toxicological } \\
\text { findings in driver and } \\
\text { motorcyclist fatalities in } \\
\text { Scotland 2012-2015. } \\
\text { Forensic Sci Int. }\end{array}$ & $\begin{array}{l}\text { What toxicological } \\
\text { profiles are observed in } \\
\text { fatally injured drivers } \\
\text { and motorcyclists? }\end{array}$ & $n=118$ & $\begin{array}{l}\text { Opioids were the } \\
\text { third most } \\
\text { common class of } \\
\text { drug detected }\end{array}$ & $\begin{array}{l}\text { Quantitative } \\
\text { analysis. }\end{array}$ & $\begin{array}{l}\text { Mixed vehicle classes } \\
\text { included, cases were } \\
63 \% \text { car drivers, } 27 \% \\
\text { motorcyclists, } 10 \% \text { other } \\
\text { vehicles. Majority of } \\
\text { fatally injured drivers } \\
\text { were men. }\end{array}$ \\
\hline
\end{tabular}

2017;274:22-6.

[72] Kumar S, Bansal YS, Singh Wh D, Medhi B. Alcohol and Drug Use in Injured Drivers - An Emergency Room Study in a Regional Tertiary Care Centre of North West India. J Clin Diagn Res. 2015;9(7):HC01-4.

[73] Movig KL, Mathijssen MP, Nagel PH, van Egmond T, de Gier JJ, Leufkens HG, et al. Psychoactive substance use and the risk of motor vehicle accidents. Accid Anal Prev. 2004;36(4):631-6.

[74] Mura P, Kintz P, Ludes B, Gaulier JM, Marquet $P$, Martin-Dupont S, et al. Comparison of the prevalence of alcohol, cannabis and other drugs between 900 injured drivers and 900 control subjects: results of a French collaborative study. Forensic Sci Int. 2003;133(1-2):79-85.

[75] Price JW. A comparison of random and post-accident urine opiate and opioid tests. $\mathrm{J}$ Addict Dis. 2015;34(1):36-42.

[76] Reguly P, Dubois S, Bedard M. Examining the impact of opioid analgesics on crash responsibility in truck drivers involved in fatal crashes. Forensic Sci Int. 2014;234:154-61.

[77] Wilson FA, Stimpson JP, Pagan JA. Fatal crashes What is the toxicologica
profile of drivers
involved in injurious crash?

$n=200$

Adequate
sample size. was the most prevalent substance consumed followed by opiates $(13 \%)$.

$\begin{array}{lcl}\text { Is there an association } & n=110, & \text { Increased risks were } \\ \text { between psychoactive } & \text { control } \\ \text { drug use and risk of } & n=816 & \begin{array}{l}\text { found for drivers } \\ \text { positive for } \\ \text { crash requiring }\end{array} \\ \text { hospitalization? } & & \text { opioids (2.35 } \\ & & \text { OR). }\end{array}$

How do the toxicological profiles of injured drivers compare to those in patients visiting the emergency department for non-trauma complaints?

\begin{tabular}{|c|c|c|}
\hline $\begin{array}{l}l=900, \\
\text { controls }= \\
900\end{array}$ & $\begin{array}{l}\text { Injured drivers had } \\
\text { an increased odds } \\
\text { ratio of } 8.2 \text { for } \\
\text { positive } \\
\text { morphine } \\
\text { toxicology. }\end{array}$ & $\begin{array}{c}\text { Large sample } \\
\text { size, age } \\
\text { matched } \\
\text { controls. }\end{array}$ \\
\hline
\end{tabular}

Accident group was Large sample 4.45 times more size. between opioid use and $n=2070$ work-related accidents? control $n=2506$
What is the relationship Population between opioid use and $n=8325$, crash responsibility in truck drivers? opioid positive $n=102$

$$
n=2363
$$
likely to be taking an opioid than the control group.

Odds of committing Age, an unsafe driving action significantly increased in individuals taking opioids.

Hydrocodone and oxycodone are size.

Age, polysubstadriving history matched controls.

Large sample

\section{Prospective case-control design, large popu- lation con- sidered.} nce use, and
Young people overrepresented in crash group. Poor case-control matching, cases were ED patients and controls were drivers randomly sampled on the roadside.

Drivers only considered "opioid positive" if morphine levels exceeded $20 \mathrm{ng} / \mathrm{mL}$. Authors do not report on other opioid toxicology or compounds.

Small number of positive urine samples, analysis does not include heroin, 6-MAM, or fentanyl, or fentanyl analogues.

Small proportion of sample tested positive, men overrepresented in study sample. size.
Study design only reveals prevalence of drug 
Table 4 (continued)

Number Citation

Research question of

Participants

Key findings

Strengths

Limitations

interest

from drivers testing

positive for drugs in the

U.S., 1993-2010. Public

Health Rep.

2014;129(4):342-50.

[78] Wong OF, Tsui KL, Lam TS, Sze NN, Wong SC, Lau FL, et al. Prevalence of drugged drivers among non-fatal driver casualties presenting to a trauma centre in Hong Kong. Hong Kong Med J. 2010;16(4):246-51.

[79] Drummer OH,

Gerostamoulos J,

Batziris H, Chu M,

Caplehorn J, Robertson

$\mathrm{MD}$, et al. The

involvement of drugs in

drivers of motor vehicles

killed in Australian road

traffic crashes. Accid

Anal Prev.

2004;36(2):239-48.

[80] Marquet P, Delpla PA,

Kerguelen S, Bremond J,

Facy F, Garnier M, et al.

Prevalence of drugs of

abuse in urine of drivers

involved in road

accidents in France: a

collaborative study. J

Forensic Sci.

1998;43(4):806-11.

[81] Drummer OH, Yap S. The involvement of prescribed drugs in road trauma. Forensic Sci Int. 2016;265:17-21.

[82] Van der Linden T, Isalberti C, Silverans P, Legrand SA, Verstraete AG. Comparison of drug concentrations measured in roadside surveys and in seriously injured drivers in Belgium. Drug Test Anal. 2013;5(7):541-8.

What toxicological

profiles are observed in

fatally injured drivers?

What are the toxicological $n=395$

profiles of injured

drivers?
Is there a relationship
between drug use and
crash culpability in

fatally injured drivers?

$n=3398$
Non-significant, weakly positive associations between positive opioid toxicology and crash culpability.

the second and

third most

frequently

observed drugs in

fatally injured

drivers.

38 drivers $(9.6 \%)$ tested positive for drugs. Of opioid positive drivers, morphine most common (31\%).

Adequate Cross-sectional design. sample size. Young people overrepresented. Participation was voluntary, subject to reporting bias. consumption, limiting conclusions.
How do the toxicological $n=296$, profiles of injured control drivers compare to $\quad n=278$ those in patients visiting the emergency department for non-trauma complaints?

What is the relationship between opioid blood toxicology and fatal crash risk?

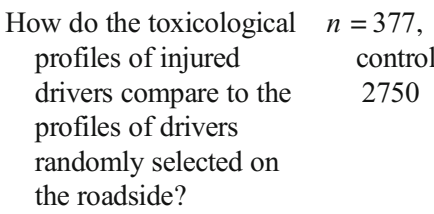

Opiates were present in $10.5 \%$ of drivers and $10.4 \%$ of patients (non-trauma). $n=2638$

Crash risk of drivers taking opioids was not increased compared to drug-free controls.

Most of the injured drivers who were positive for opioids had sub-therapeutic concentrations in their systems.
Multicenter Drivers showing the case-control highest culpability rates study de- were in the under 25 and sign. over 65 age groups, indicating that age may be a confounding variable.

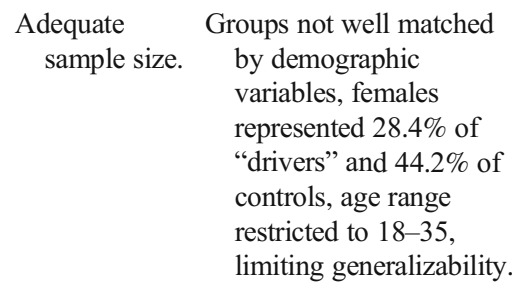

Adequate Groups not well matched sample size. by demographic variables, females represented $28.4 \%$ of "drivers" and $44.2 \%$ of controls, age range restricted to $18-35$, limiting generalizability.

Large sample size.
Difficult to control for presence of confounding variables at time of crash.
Multicenter Limited sample size, results case-control potentially implicate study de- uncontrolled pain as a sign. risk factor for serious crash.

conclusion that there is an increased risk of impairment and/or crash involvement associated with prescription opioid use. Fifty-two percent of studies considered favor the conclusion that opioids impair driving or driving-related neurocognitive performance. Some data note an increased risk specifically with the initiation of treatment or first-time prescribing and other studies note that no increased risk is observed when comparing the performance of patients on stable, chronic 
Table 5 Studies that demonstrate the role of polydrug use on driving and driving-related neurocognitive performance in individuals consuming opioids

Number Citation $\quad$ Research question of Participants Key findings $\quad$ Strengths Limitations

interest

[83] Bachs LC, Engeland A, Morland JG, Skurtveit S. The risk of motor vehicle accidents involving drivers with prescriptions for codeine or tramadol. Clin Pharmacol Ther. 2009;85(6):596-9.

Bernard JP, Morland J, Krogh M, Khiabani HZ. Methadone and impairment in apprehended drivers. Addiction. 2009;104(3):457-64.

[85] Chihuri S, Li G. Trends in Prescription Opioids Detected in Fatally Injured Drivers in 6 US States: 1995-2015. Am J Public Health. 2017;107(9):1487-92.

[86] Jonasson U, Jonasson B, Saldeen T, Thuen F. The prevalence of analgesics containing dextropropoxyphene or codeine in individuals suspected of driving under the influence of drugs. Forensic Sci Int. 2000;112(2-3):163-9.

[87] Jones AW, Kugelberg FC, Holmgren A, Ahlner J. Five-year update on the occurrence of alcohol and other drugs in blood samples from drivers killed in road traffic crashes in Sweden.

Forensic Sci Int. 2009;186(1-3):56-62.

[88] Li G, Brady JE, Chen Q. Drug use and fatal motor vehicle crashes: a case-control study. Accid Anal Prev. 2013;60:205-10.

[89] Musshoff F, Lachenmeier DW, Madea B.

Methadone substitution: medicolegal problems in Germany. Forensic Sci

$\begin{array}{ll}\text { Are drivers who have } & \text { Crash } \\ \text { filled a prescription for } & n=201 \\ \text { codeine or tramadol at } & (181 \\ \text { increased crash risk } & \text { codein- } \\ \text { involving serious injury } & \mathrm{e}+, 20 \\ \text { compared with age } & \text { trama- } \\ \text { matched controls? } & \text { dol+) }\end{array}$

What rates of

$n=635$

co-intoxication exist in moving violation cases in which methadone was detected in the blood of drivers?

What opioid toxicological profiles are seen in fatally injured drivers?

$n=36,729$

Of the deceased drivers

What is the prevalence of $n=4896$ dextropropoxyphene and codeine in body fluid samples taken from individuals suspected of driving under the influence?

What opioid toxicological $n=1403$ profiles are seen in fatally injured drivers?

What is the association between psychoactive drug use and fatal crash risk?

$n=737$,
$\quad$ control
$n=771-$
9

What rates of $n=153$ co-intoxication exist in moving violation cases in which methadone who were positive for prescription opioids, $30 \%$ had elevated blood alcohol and $67 \%$ tested positive for other drugs.

Risk of being involved in Large

an accident was increased for drivers using codeine but not tramadol. Codeine result becomes non-significant when you control for co-prescription of other psychoactive substances.

Extremely high rates of polypharmacy present, methadone was the only psychoactive drug detected in blood in $1.5 \%$ of cases.

486 cases where dextropropoxyphene and/or codeine were found, polydrug use in all but 28 cases. In $71 \%$ of the 486 cases, benzodiazepines were also present and in 38\% of the cases amphetamine and/or cannabis were present.

Mean 2.4 drugs/person in cases with positive opioid toxicology, most frequently detected classes of drug were sedative-hypnotics, followed by opioids. age size. size. longitudinal data set analyzed, matched controls.

Confounder: of 83 codeine exposed subjects, 65 had been prescribed other psychoactive drugs near filling their codeine prescription.

Large
population
studied

Majority of drivers were men with history of heroin abuse aged between 30 and 40 years, limits generalizability.

Very large There is concern that population this sample is not studied representative as some evidence (90) shows most states do not follow testing protocols.

Longitudinal Only considered 2 study, opioid drugs.

large sample

Large sample $83 \%$ of individuals involved in fatal crashes were men, limits generalizability.
Increased odds ratio (4.83) Large of being involved in a fatal crash for drivers using "non-alcohol depressants", which includes opioids as well as other classes of drugs such as benzodiazepines.

Methadone was the only drug detected in just $4.5 \%$ of cases, high rates of use of population studied.

Authors grouped opioids and benzodiazepines together when analyzing the data, unable to distinguish drug effects.

Large
population
studied.

$87 \%$ of those who drove while taking methadone were men, limits generalizability. 
Table 5 (continued)

\begin{tabular}{|c|c|c|c|c|c|c|}
\hline Number & Citation & $\begin{array}{l}\text { Research question of } \\
\text { interest }\end{array}$ & Participants & Key findings & Strengths & Limitations \\
\hline & $\begin{array}{l}\text { Int. } \\
2003 ; 133(1-2): 118-24 .\end{array}$ & $\begin{array}{l}\text { was detected in the } \\
\text { blood of drivers? }\end{array}$ & & $\begin{array}{l}\text { benzodiazepines, } \\
\text { alcohol, and morphine. }\end{array}$ & & \\
\hline
\end{tabular}

regimens compared to healthy controls. This suggests that individuals on stable, chronic regimens without additional risk factors, such as substance abuse disorder, may be considered a group of opioid users at lower risk for impairment. Answers about who is safe to operate a motor vehicle while using prescription opioids must be given individual consideration with examination of baseline risks and comorbidities which may influence neurocognitive function and/or driving performance (e.g., age, medical comorbidity). Significant variability in study design, sample size, and methodology exists in the studies considered in this section, and selection bias and confounding variables are present. The presence of these biases suggest that factors intrinsic to the populations considered (e.g., age, sex) may modulate driving risk as it relates to opioid drugs to a significant degree.

Positive opioid toxicology was shown to be associated with increased risk of injury, unsafe driving, or crash in the majority of studies considered. $69 \%$ of studies considered favor the conclusion that opioids impair driving or driving-related neurocognitive performance. This generally supports the conclusion that there is some population level risk associated with the consumption of opioid drugs. However, some studies suggest no impact of opioid drugs. It is possible that other variables including population characteristics, methodology, baseline pain, substance abuse, and/or sample size may act as confounding variables and/or mediate crash risk to a greater degree than the presence or absence of opioids. A common limitation among many studies which rely on toxicologic data is the inability and/or failure to differentiate between prescription and illicit use. As such, the data in these studies may only reflect the prevalence of drug consumption and not the circumstances of consumption, limiting the conclusions which may be drawn.

Polydrug use is observed to be frequent in populations consuming opioid drugs. The presence of polydrug use in these studies precludes our ability to draw conclusions about the impact of opioid drugs. However, they highlight the prevalence of polydrug use as a confounding variable that is difficult to avoid when studying populations consuming opioids. These studies demonstrate the safety risks associated with polydrug use as well as highlight the importance of discussing the impact of polydrug use on psychomotor function and complex tasks with all patients who consume multiple psychoactive drugs, including opioids.

\section{Limitations}

It is important to acknowledge the limitations of this review. Most importantly, the heterogeneity of studies included in this review precludes the use of validated assessments of study quality (e.g., GRADE). In general, due to the difficult nature of studying opioid drug use and driving, a majority of studies included are considered to be of low quality due to small sample size, selection bias, and the presence of confounding variables. Although some literature on the topic of impairment associated with opioid use might have been published prior to 1992, we limited our search to those studies published after 1992 to meet the aims of our current review.

\section{Conclusion}

Illicit use, the use of opioid drugs in combination with other psychoactive medications, and the initiation of opioid therapy are contexts most clearly associated with impairment of neurocognitive and psychomotor functions as they pertain to complex tasks including the operation of a motor vehicle. Variables besides drug consumption may significantly mediate crash risk in populations consuming opioid drugs including gender, age, and comorbid medical conditions. Clinicians should counsel patients on the risk of driving impairment when initiating opioid therapy, when adding psychoactive drugs to an existing opioid regimen, or when the clinician suspects a patient uses opioids illicitly.

\section{Compliance with Ethical Standards}

Conflict of Interest None.

\section{References}

1. Jewett A, Shults RA, Banerjee T, Bergen G. Alcohol-impaired driving among adults-United States, 2012. MMWR Morb Mortal Wkly Rep. 2015;64(30):814-7.

2. Hemmings HC, Egan TD. Pharmacology and Physiology for Anesthesia: Foundations and Clinical Application. Second ed. Elsevier; October 19, 2018. 994 p

3. Trescot AM, Datta S, Lee M, Hansen H. Opioid pharmacology. Pain Physician. 2008;11(2 Suppl):S133-53. 
4. Al-Hasani R, Bruchas MR. Molecular mechanisms of opioid receptor-dependent signaling and behavior. Anesthesiology. 2011;115(6):1363-81.

5. Gottas A, Oiestad EL, Boix F, Vindenes V, Ripel A, Thaulow CH, et al. Levels of heroin and its metabolites in blood and brain extracellular fluid after i.v. heroin administration to freely moving rats. Br J Pharmacol. 2013;170(3):546-56.

6. Black ML, Hill JL, Zacny JP. Behavioral and physiological effects of remifentanil and alfentanil in healthy volunteers. Anesthesiology. 1999;90(3):718-26.

7. Cherrier MM, Amory JK, Ersek M, Risler L, Shen DD. Comparative cognitive and subjective side effects of immediaterelease oxycodone in healthy middle-aged and older adults. $\mathrm{J}$ Pain. 2009;10(10):1038-50.

8. Jensen ML, Sjogren P, Upton RN, Foster DJ, Bonde P, Graae C, et al. Pharmacokinetic-pharmacodynamic relationships of cognitive and psychomotor effects of intravenous buprenorphine infusion in human volunteers. Basic Clin Pharmacol Toxicol. 2008;103(1):94 101.

9. Schneider U, Bevilacqua C, Jacobs R, Karst M, Dietrich DE, Becker $\mathrm{H}$, et al. Effects of fentanyl and low doses of alcohol on neuropsychological performance in healthy subjects. Neuropsychobiology. 1999;39(1):38-43.

10. Thapar P, Zacny JP, Choi M, Apfelbaum JL. Objective and subjective impairment from often-used sedative/analgesic combinations in ambulatory surgery, using alcohol as a benchmark. Anesth Analg. 1995;80(6):1092-8.

11. Walker DJ, Zacny JP. Subjective, psychomotor, and physiological effects of cumulative doses of opioid mu agonists in healthy volunteers. J Pharmacol Exp Ther. 1999;289(3):1454-64.

12. Walker DJ, Zacny JP, Galva KE, Lichtor JL. Subjective, psychomotor, and physiological effects of cumulative doses of mixedaction opioids in healthy volunteers. Psychopharmacology. 2001;155(4):362-71.

13. Zacny JP. Characterizing the subjective, psychomotor, and physiological effects of a hydrocodone combination product (Hycodan) in non-drug-abusing volunteers. Psychopharmacology. 2003;165(2): 146-56.

14. Zacny JP, Conley K, Galinkin J. Comparing the subjective, psychomotor and physiological effects of intravenous buprenorphine and morphine in healthy volunteers. J Pharmacol Exp Ther. 1997;282(3):1187-97.

15. Zacny JP, Gutierrez S, Bolbolan SA. Profiling the subjective, psychomotor, and physiological effects of a hydrocodone/ acetaminophen product in recreational drug users. Drug Alcohol Depend. 2005;78(3):243-52.

16. Zacny JP, Gutierrez S. Characterizing the subjective, psychomotor, and physiological effects of oral oxycodone in non-drug-abusing volunteers. Psychopharmacology. 2003;170(3):242-54.

17. Zacny JP, Gutierrez S. Within-subject comparison of the psychopharmacological profiles of oral hydrocodone and oxycodone combination products in non-drug-abusing volunteers. Drug Alcohol Depend. 2009;101(1-2):107-14.

18. Zacny JP, Hill JL, Black ML, Sadeghi P. Comparing the subjective, psychomotor and physiological effects of intravenous pentazocine and morphine in normal volunteers. J Pharmacol Exp Ther. 1998;286(3):1197-207.

19. Zacny JP, Lichtor SA. Within-subject comparison of the psychopharmacological profiles of oral oxycodone and oral morphine in non-drug-abusing volunteers. Psychopharmacology. 2008;196(1): $105-16$.

20. Zacny JP, Lichtor JL, Binstock W, Coalson DW, Cutter T, Flemming DC, et al. Subjective, behavioral and physiological responses to intravenous meperidine in healthy volunteers. Psychopharmacology. 1993;111(3):306-14.
21. Zacny JP, Lichtor JL, Flemming D, Coalson DW, Thompson WK. A dose-response analysis of the subjective, psychomotor and physiological effects of intravenous morphine in healthy volunteers. J Pharmacol Exp Ther. 1994;268(1):1-9.

22. Zacny JP, Lichtor JL, Klafta JM, Alessi R, Apfelbaum JL. The effects of transnasal butorphanol on mood and psychomotor functioning in healthy volunteers. Anesth Analg. 1996;82(5):931-5.

23. Zacny JP, Lichtor JL, Thapar P, Coalson DW, Flemming D, Thompson WK. Comparing the subjective, psychomotor and physiological effects of intravenous butorphanol and morphine in healthy volunteers. J Pharmacol Exp Ther. 1994;270(2):579-88.

24. Zacny JP, Lichtor JL, Zaragoza JG, de Wit H. Subjective and behavioral responses to intravenous fentanyl in healthy volunteers. Psychopharmacology. 1992;107(2-3):319-26.

25. Zacny JP, Paice JA, Coalson DW. Separate and combined psychopharmacological effects of alprazolam and oxycodone in healthy volunteers. Drug Alcohol Depend. 2012;124(3):274-82.

26. O'Neill WM, Hanks GW, Simpson P, Fallon MT, Jenkins E, Wesnes K. The cognitive and psychomotor effects of morphine in healthy subjects: a randomized controlled trial of repeated (four) oral doses of dextropropoxyphene, morphine, lorazepam and placebo. Pain. 2000;85(1-2):209-15.

27. Verster JC, Veldhuijzen DS, Volkerts ER. Effects of an opioid (oxycodone/paracetamol) and an NSAID (bromfenac) on driving ability, memory functioning, psychomotor performance, pupil size, and mood. Clin J Pain. 2006;22(5):499-504.

28. Amato JN, Marie S, Lelong-Boulouard V, Paillet-Loilier M, Berthelon C, Coquerel A, et al. Effects of three therapeutic doses of codeine/paracetamol on driving performance, a psychomotor vigilance test, and subjective feelings. Psychopharmacology. 2013;228(2):309-20.

29. Brown TL, Milavetz G, Gaffney G, Spurgin A. Evaluating drugged driving: Effects of exemplar pain and anxiety medications. Traffic Inj Prev. 2018;19(sup1):S97-S103.

30. Pickworth WB, Rohrer MS, Fant RV. Effects of abused drugs on psychomotor performance. Exp Clin Psychopharmacol. 1997;5(3): 235-41.

31. Walker DJ, Zacny JP. Subjective, psychomotor, and analgesic effects of oral codeine and morphine in healthy volunteers. Psychopharmacology. 1998;140(2):191-201.

32. Zacny JP. Profiling the subjective, psychomotor, and physiological effects of tramadol in recreational drug users. Drug Alcohol Depend. 2005;80(2):273-8.

33. Zacny JP, Goldman RE. Characterizing the subjective, psychomotor, and physiological effects of oral propoxyphene in non-drugabusing volunteers. Drug Alcohol Depend. 2004;73(2):133-40.

34. Zacny JP, Gutierrez S. Subjective, psychomotor, and physiological effects of oxycodone alone and in combination with ethanol in healthy volunteers. Psychopharmacology. 2011;218(3):471-81.

35. Asbridge $M$, Cartwright J, Langille D. Driving under the influence of opioids among high school students in Atlantic Canada: prevalence, correlates, and the role of medical versus recreational consumption. Accid Anal Prev. 2015;75:184-91.

36. Bachs L, Hoiseth G, Skurtveit S, Morland J. Heroin-using drivers: importance of morphine and morphine-6-glucuronide on late clinical impairment. Eur J Clin Pharmacol. 2006;62(11):905-12.

37. Bassiony MM, Youssef UM, Hassan MS, Salah El-Deen GM, ElGohari $\mathrm{H}$, Abdelghani M, et al. Cognitive impairment and tramadol dependence. J Clin Psychopharmacol. 2017;37(1):61-6.

38. Ceder G, Jones AW. Concentration ratios of morphine to codeine in blood of impaired drivers as evidence of heroin use and not medication with codeine. Clin Chem. 2001;47(11):1980-4.

39. Jones AW, Holmgren A, Kugelberg FC. Driving under the influence of opiates: concentration relationships between morphine, codeine, 6-acetyl morphine, and ethyl morphine in blood. J Anal Toxicol. 2008;32(4):265-72. 
40. Wang GY, Wouldes TA, Kydd R, Jensen M, Russell BR. Neuropsychological performance of methadone-maintained opiate users. J Psychopharmacol. 2014;28(8):789-99.

41. Buckeridge D, Huang A, Hanley J, Kelome A, Reidel K, Verma A, et al. Risk of injury associated with opioid use in older adults. J Am Geriatr Soc. 2010;58(9):1664-70.

42. Engeland A, Skurtveit S, Morland J. Risk of road traffic accidents associated with the prescription of drugs: a registry-based cohort study. Ann Epidemiol. 2007;17(8):597-602.

43. French DD, Campbell R, Spehar A, Cunningham F, Bulat T, Luther SL. Drugs and falls in community-dwelling older people: a national veterans study. Clin Ther. 2006;28(4):619-30.

44. Gibson JE, Hubbard RB, Smith CJ, Tata LJ, Britton JR, Fogarty AW. Use of self-controlled analytical techniques to assess the association between use of prescription medications and the risk of motor vehicle crashes. Am J Epidemiol. 2009;169(6):761-8.

45. Gomes T, Redelmeier DA, Juurlink DN, Dhalla IA, Camacho X, Mamdani MM. Opioid dose and risk of road trauma in Canada: a population-based study. JAMA Intern Med. 2013;173(3):196-201.

46. Karjalainen K, Haukka J, Lintonen T, Joukamaa M, Lillsunde P. The use of psychoactive prescription drugs among DUI suspects. Drug Alcohol Depend. 2015;155:215-21.

47. Leveille SG, Buchner DM, Koepsell TD, McCloskey LW, Wolf ME, Wagner EH. Psychoactive medications and injurious motor vehicle collisions involving older drivers. Epidemiology. 1994;5(6):591-8.

48. Marco CA, Mann D, Rasp J, Ballester M, Perkins O, Holbrook MB, et al. Effects of opioid medications on cognitive skills among emergency department patients. Am J Emerg Med. 2018;36(6):1009-13.

49. Meuleners LB, Duke J, Lee AH, Palamara P, Hildebrand J, Ng JQ. Psychoactive medications and crash involvement requiring hospitalization for older drivers: a population-based study. J Am Geriatr Soc. 2011;59(9):1575-80.

50. Monarrez-Espino J, Laflamme L, Rausch C, Elling B, Moller J. New opioid analgesic use and the risk of injurious single-vehicle crashes in drivers aged 50-80 years: a population-based matched case-control study. Age Ageing. 2016;45(5):628-34.

51. Rudisill TM, Zhu M, Davidov D, Leann Long D, Sambamoorthi U, Abate M, et al. Medication use and the risk of motor vehicle collision in West Virginia drivers 65 years of age and older: a casecrossover study. BMC Res Notes. 2016;9:166.

52. Schiltenwolf M, Akbar M, Hug A, Pfuller U, Gantz S, Neubauer E, et al. Evidence of specific cognitive deficits in patients with chronic low back pain under long-term substitution treatment of opioids. Pain Physician. 2014;17(1):9-20.

53. Shorr RI, Griffin MR, Daugherty JR, Ray WA. Opioid analgesics and the risk of hip fracture in the elderly: codeine and propoxyphene. J Gerontol. 1992;47(4):M111-5.

54. Sjogren $\mathrm{P}$, Thomsen AB, Olsen AK. Impaired neuropsychological performance in chronic nonmalignant pain patients receiving longterm oral opioid therapy. J Pain Symptom Manag. 2000;19(2):1008 .

55. Soderberg KC, Laflamme L, Moller J. Newly initiated opioid treatment and the risk of fall-related injuries. A nationwide, registerbased, case-crossover study in Sweden. CNS Drugs. 2013;27(2): 155-61.

56. Jamison RN, Schein JR, Vallow S, Ascher S, Vorsanger GJ, Katz NP. Neuropsychological effects of long-term opioid use in chronic pain patients. J Pain Symptom Manag. 2003;26(4):913-21.

57. Sabatowski R, Scharnagel R, Gyllensvard A, Steigerwald I. Driving ability in patients with severe chronic low back or osteoarthritis knee pain on stable treatment with tapentadol prolonged release: a multicenter, open-label, phase 3b trial. Pain Ther. 2014;3(1):17-29.

58. Schumacher MB, Jongen S, Knoche A, Petzke F, Vuurman EF, Vollrath M, et al. Effect of chronic opioid therapy on actual driving performance in non-cancer pain patients. Psychopharmacology. 2017;234(6):989-99.

59. Strumpf M, Willweber-Strumpf A, Herberg KW, Zenz M. Safetyrelevant performance of patients on chronic opioid therapy. Schmerz. 2005;19(5):426-33.

60. Byas-Smith MG, Chapman SL, Reed B, Cotsonis G. The effect of opioids on driving and psychomotor performance in patients with chronic pain. Clin J Pain. 2005;21(4):345-52.

61. Dagtekin O, Gerbershagen HJ, Wagner W, Petzke F, Radbruch L, Sabatowski R. Assessing cognitive and psychomotor performance under long-term treatment with transdermal buprenorphine in chronic noncancer pain patients. Anesth Analg. 2007;105(5): 1442-8 table of contents.

62. Gaertner J, Radbruch L, Giesecke T, Gerbershagen H, Petzke F, Ostgathe $\mathrm{C}$, et al. Assessing cognition and psychomotor function under long-term treatment with controlled release oxycodone in non-cancer pain patients. Acta Anaesthesiol Scand. 2006;50(6): 664-72.

63. Hooper TI, DeBakey SF, Pearse L, Pratt S, Hoffman KJ. The use of electronic pharmacy data to investigate prescribed medications and fatal motor vehicle crashes in a military population, 2002-2006. Accid Anal Prev. 2010;42(1):261-8.

64. Krebs EE, Paudel M, Taylor BC, Bauer DC, Fink HA, Lane NE, et al. Association of opioids with falls, fractures, and physical performance among older men with persistent musculoskeletal pain. J Gen Intern Med. 2016;31(5):463-9.

65. Menefee LA, Frank ED, Crerand C, Jalali S, Park J, Sanschagrin K, et al. The effects of transdermal fentanyl on driving, cognitive performance, and balance in patients with chronic nonmalignant pain conditions. Pain Med. 2004;5(1):42-9.

66. Nilsen HK, Landro NI, Kaasa S, Jenssen GD, Fayers P, Borchgrevink PC. Driving functions in a video simulator in chronic non-malignant pain patients using and not using codeine. Eur $\mathrm{J}$ Pain. 2011;15(4):409-15.

67. Ray WA, Fought RL, Decker MD. Psychoactive drugs and the risk of injurious motor vehicle crashes in elderly drivers. Am J Epidemiol. 1992;136(7):873-83.

68. Sabatowski R, Schwalen S, Rettig K, Herberg KW, Kasper SM, Radbruch L. Driving ability under long-term treatment with transdermal fentanyl. J Pain Symptom Manag. 2003;25(1):38-47.

69. Tassain V, Attal N, Fletcher D, Brasseur L, Degieux P, Chauvin M, et al. Long term effects of oral sustained release morphine on neuropsychological performance in patients with chronic non-cancer pain. Pain. 2003;104(1-2):389-400.

70. Dubois S, Bedard M, Weaver B. The association between opioid analgesics and unsafe driving actions preceding fatal crashes. Accid Anal Prev. 2010;42(1):30-7.

71. Hamnett HJ, Ilett M, Izzati F, Smith SS, Watson KH. Toxicological findings in driver and motorcyclist fatalities in Scotland 2012-2015. Forensic Sci Int. 2017;274:22-6.

72. Kumar S, Bansal YS, Singh D, Medhi B. Alcohol and drug use in injured drivers - an emergency room study in a regional tertiary care centre of North West India. J Clin Diagn Res. 2015;9(7):HC01-4.

73. Movig KL, Mathijssen MP, Nagel PH, van Egmond T, de Gier JJ, Leufkens HG, et al. Psychoactive substance use and the risk of motor vehicle accidents. Accid Anal Prev. 2004;36(4):631-6.

74. Mura P, Kintz P, Ludes B, Gaulier JM, Marquet P, Martin-Dupont $\mathrm{S}$, et al. Comparison of the prevalence of alcohol, cannabis and other drugs between 900 injured drivers and 900 control subjects: results of a French collaborative study. Forensic Sci Int. 2003;133(1-2):79-85.

75. Price JW. A comparison of random and post-accident urine opiate and opioid tests. J Addict Dis. 2015;34(1):36-42.

76. Reguly P, Dubois S, Bedard M. Examining the impact of opioid analgesics on crash responsibility in truck drivers involved in fatal crashes. Forensic Sci Int. 2014;234:154-61. 
77. Wilson FA, Stimpson JP, Pagan JA. Fatal crashes from drivers testing positive for drugs in the U.S., 1993-2010. Public Health Rep. 2014;129(4):342-50.

78. Wong OF, Tsui KL, Lam TS, Sze NN, Wong SC, Lau FL, et al. Prevalence of drugged drivers among non-fatal driver casualties presenting to a trauma centre in Hong Kong. Hong Kong Med J. 2010;16(4):246-51.

79. Drummer OH, Gerostamoulos J, Batziris H, Chu M, Caplehorn J, Robertson MD, et al. The involvement of drugs in drivers of motor vehicles killed in Australian road traffic crashes. Accid Anal Prev. 2004;36(2):239-48.

80. Marquet P, Delpla PA, Kerguelen S, Bremond J, Facy F, Garnier $\mathrm{M}$, et al. Prevalence of drugs of abuse in urine of drivers involved in road accidents in France: a collaborative study. J Forensic Sci. 1998;43(4):806-11.

81. Drummer OH, Yap S. The involvement of prescribed drugs in road trauma. Forensic Sci Int. 2016;265:17-21.

82. Van der Linden T, Isalberti C, Silverans P, Legrand SA, Verstraete AG. Comparison of drug concentrations measured in roadside surveys and in seriously injured drivers in Belgium. Drug Test Anal. 2013;5(7):541-8.

83. Bachs LC, Engeland A, Morland JG, Skurtveit S. The risk of motor vehicle accidents involving drivers with prescriptions for codeine or tramadol. Clin Pharmacol Ther. 2009;85(6):596-9.
84. Bernard JP, Morland J, Krogh M, Khiabani HZ. Methadone and impairment in apprehended drivers. Addiction. 2009;104(3):45764.

85. Chihuri S, Li G. Trends in prescription opioids detected in fatally injured drivers in 6 US states: 1995-2015. Am J Public Health. 2017;107(9):1487-92.

86. Jonasson U, Jonasson B, Saldeen T, Thuen F. The prevalence of analgesics containing dextropropoxyphene or codeine in individuals suspected of driving under the influence of drugs. Forensic Sci Int. 2000;112(2-3):163-9.

87. Jones AW, Kugelberg FC, Holmgren A, Ahlner J. Five-year update on the occurrence of alcohol and other drugs in blood samples from drivers killed in road-traffic crashes in Sweden. Forensic Sci Int. 2009;186(1-3):56-62.

88. Li G, Brady JE, Chen Q. Drug use and fatal motor vehicle crashes: a case-control study. Accid Anal Prev. 2013;60:205-10.

89. Musshoff F, Lachenmeier DW, Madea B. Methadone substitution: medicolegal problems in Germany. Forensic Sci Int. 2003;133(12):118-24.

Publisher's Note Springer Nature remains neutral with regard to jurisdictional claims in published maps and institutional affiliations. 